\title{
Vitamin D status after resection of ileum in childhood
}

\author{
M. A. PREECE and H. B. VALMAN \\ From Middlesex Hospital, London, and Northwick Park Hospital and Clinical Reseach Centre, \\ Harrow, Middlesex
}

\begin{abstract}
Preece, M. A., and Valman, H. B. (1975). Archives of Disease in Childhood, 50, 283. Vitamin $D$ status after resection of ileum in childhood. Serum 25hydroxycholecalciferol levels and $x$-rays of the wrist were normal in children who had had extensive resections of ileum and no supplementary vitamin $\mathrm{D}$ for considerable periods. These results suggest that normal vitamin $D$ status occurs in the absence of the ileum and that supplementary vitamin $\mathrm{D}$ is unnecessary.
\end{abstract}

Booth, MacIntyre, and Mollin (1964) studied several adult patients who had had extensive resections of ileum and suggested that they should receive monthly injections of vitamin $\mathrm{D}$ to prevent bone disease. This was based on the observation in one patient that calcium absorption was increased by a single intramuscular injection of 100000 units calciferol. Subsequently tritium-labelled vitamin $\mathrm{D}$ was used to show in one patient that a small jejunal remnant was capable of efficient vitamin D absorption (Thompson et al., 1965), but the original recommendation of Booth et al. continued to be standard practice (Young, Swain, and Pringle, 1969).

Absorption of vitamin $\mathrm{D}$ occurs only in the presence of bile salts (Schachter, Finkelstein, and Kowarski, 1964) which are reabsorbed mainly by an active transport system in the ileum (Baker and Searle, 1960). Estimations of the size of the bile salt pool are usually made after an overnight fast, and after ileal resection the pool may appear only slightly reduced (Abaurre et al., 1969). After ileal resection the concentration of bile salts in the jejunum falls progressively during the day due to loss of the bile salt pool from malabsorption (Van Deest et al., 1968). Though the degree of malabsorption may be related to the length of remaining ileum or ability of the jejunum or colon to take over the function of the ileum, resection of only $40 \mathrm{~cm}$ of terminal ileum in the adult is associated with severe malabsorption of bile salts (Woodbury, Kern, and Palmer, 1970).

Until recently methods of assessing vitamin D status had largely been indirect. The only assay for circulating vitamin $\mathrm{D}$ concentration had been bioassay which was inconvenient and imprecise at low levels, and other methods were unsuitable for

Received 10 September 1974. biological extracts. In this study we have used a competitive protein binding technique to measure serum 25-hydroxycholicalciferol (25-HCC) concentrations in a group of 8 children who had undergone extensive ileal resection, and who had received no supplementary vitamin $D$ for considerable periods.

\section{Patients and methods}

Details of the patients are shown in Table I. All were receiving normal diets and no vitamin supplements at the time of this study, and none had had persistent diarrhoea after the age of 2 years.

Serum 25-HCC concentration was measured by the method of Preece et al. (1974a). The normal range is $3 \cdot 8-32 \cdot 8 \mathrm{ng} / \mathrm{ml}$ with a mean of $11 \cdot 7 \mathrm{ng} / \mathrm{ml}$; there is no difference between adults and children. Plasma calcium was estimated by the method of Bachra, Dauer, and Sobel (1958), plasma phosphorus as described by Shinowara, Jones, and Reinhart (1942), plasma alkaline phosphatase according to Bessey, Lowry, and Brock (1946), and faecal fat by the method of Van de Kamer (1958). The normal ranges for children for all these investigations are shown in Table II. Serum 5-nucleotidase was determined according to Campbell (1962), in 2 patients with raised plasma alkaline phosphatase levels the normal range being 1.6-17.0 IU/1.

\section{Results}

Plasma calcium and phosphorus concentrations were normal in all the children (Table II), but 2 had raised plasma alkaline phosphatase concentrations associated with normal serum 5-nucleotidase concentrations $(3 \cdot 3$ and $9 \cdot 2 \mathrm{IU} / \mathrm{l})$. Serum $25-\mathrm{HCC}$ concentration was measured in 8 of the children and in all but one the concentrations were normal. In case 9 a concentration of $3.3 \mathrm{ng} / \mathrm{ml}$ was found. This is strictly below the lower limit of normal but 
TABLE I

Clinical details

\begin{tabular}{|c|c|c|c|c|c|c|}
\hline $\begin{array}{l}\text { Case } \\
\text { no. }\end{array}$ & $\begin{array}{c}\text { Age } \\
\text { (years) }\end{array}$ & $\begin{array}{c}\text { Age at resection } \\
\text { (years) }\end{array}$ & $\begin{array}{c}\text { Terminal ileum } \\
\text { left }(\mathrm{cm})\end{array}$ & $\begin{array}{c}\text { Small gut left } \\
\text { (cm at laparotomy) }\end{array}$ & $\begin{array}{l}\text { Small gut removed } \\
\text { (cm fixed specimen) }\end{array}$ & $\begin{array}{c}\text { Period since } \\
\text { supplementary } \\
\text { vitamin D (years) }\end{array}$ \\
\hline $\begin{array}{r}1 \\
2 \\
3 \\
4 \\
5 \\
6 \\
7 \\
8 \\
9 \\
10 \\
11 \\
12\end{array}$ & $\begin{array}{r}16 \\
15 \\
14 \\
9 \\
8 \\
8 \\
8 \\
3 \\
8 \\
8 \\
7 \\
14\end{array}$ & $\begin{array}{c}\text { Newborn } \\
\text { " } \\
\text { " } \\
\text { " } \\
\text { " } \\
\text { " } \\
1 \cdot 5,2 \cdot 5 \\
3 \\
5 \\
10\end{array}$ & $\begin{array}{r}30 \\
15 \\
0 \\
12 \\
2 \\
0 \\
10 \\
26 \\
0 \\
7 \\
2 \\
0\end{array}$ & $\begin{array}{l}- \\
- \\
65 \\
65 \\
80 \\
78 \\
40 \\
\overline{127} \\
\overline{155}\end{array}$ & $\begin{array}{l}53 \\
67 \\
65 \\
90 \\
100 \\
73 \\
48 \\
125 \\
28+65 \\
220 \\
130 \\
81\end{array}$ & $\begin{array}{c}4 \\
14 \\
12 \\
7 \\
\text { Not given } \\
7 \\
\text { Not given } \\
0 \cdot 5 \\
\text { Not given } \\
\text { " } \\
\text { " }\end{array}$ \\
\hline
\end{tabular}

as this sample was obtained in April and the normal range was established in autumn and early winter it should not be considered pathological (Stamp and Round, 1974). The mean concentration of 25-HCC in the 8 children was $10 \cdot 2 \pm 6 \cdot 0 \mathrm{ng} / \mathrm{ml}$ (mean \pm SD). This is not significantly different from that found in normal adults and children $(11 \cdot 7 \pm 5 \cdot 5$ $\mathrm{ng} / \mathrm{ml}$ ). $X$-rays of the wrist were normal in all 12 children.

\section{Discussion}

It is now known that 25-HCC is the main circulating form of cholecalciferol (vitamin $\mathrm{D}_{3}$ ) and that 25-hydroxyergocalciferol (25-HEC) is similarly related to ergocalciferol (vitamin $D_{2}$ ). Both the 25-hydroxy derivatives are formed in the liver from the parent compound and circulate in the serum bound to a specific binding protein.
Measurement of these compounds by competitive protein binding assay now provides a quick and direct estimate of vitamin $\mathrm{D}$ status. In the assay used here 25-HCC and 25-HEC are measured equally (Preece et al., 1974a) and therefore the results expressed as $25-\mathrm{HCC}$ show total $25-\mathrm{OH}$ vitamin D.

These 8 children have had major resections of the ileum which probably have severely impaired reabsorption of bile salts and thus reduced absorption of vitamin $\mathrm{D}$. As the majority of the children had resections or stopped vitamin D supplements at least 4 years before this study, vitamin D deficiency would have produced radiological evidence of rickets. It is known that in total biliary atresia wrist $x$-rays usually appear abnormal within 6 months of birth, whereas the $x$-rays in the present study were normal.

TABLE II

Biochemical results

\begin{tabular}{|c|c|c|c|c|c|c|}
\hline Case no. & $\begin{array}{c}\text { Serum 25-HCC } \\
(\mathrm{ng} / \mathrm{ml})\end{array}$ & $\begin{array}{c}\text { Plasma } \\
\text { alkaline } \\
\text { phosphatase } \\
(\mu \mathrm{mol} / 1 \text { per } \mathrm{min})\end{array}$ & $\begin{array}{c}\text { Plasma } \\
\text { calcium } \\
(\mathrm{mg} / 100 \mathrm{ml})\end{array}$ & $\begin{array}{c}\text { Plasma } \\
\text { phosphorus } \\
(\mathrm{mg} / 100 \mathrm{ml})\end{array}$ & $\begin{array}{l}\text { Faecal fat } \\
(\mathbf{g} / \mathrm{d})\end{array}$ & $\begin{array}{l}\text { Fat intake } \\
(\mathrm{g} / \mathrm{d})\end{array}$ \\
\hline $\begin{array}{r}1 \\
2 \\
3 \\
4 \\
5 \\
6 \\
7 \\
8 \\
9 \\
10 \\
11 \\
12\end{array}$ & $\begin{array}{c}4 \cdot 7 \\
\overline{12 \cdot 0} \\
20 \cdot 6 \\
\overline{6 \cdot 2} \\
\overline{16 \cdot 0} \\
3 \cdot 3 \\
12 \cdot 2 \\
\frac{6}{6 \cdot 6}\end{array}$ & $\begin{array}{l}161 \\
139 \\
160 \\
258 \\
173 \\
139 \\
120 \\
159 \\
281 \\
136 \\
140 \\
129\end{array}$ & $\begin{array}{r}9.6 \\
10.0 \\
9.6 \\
10.4 \\
9.8 \\
9.3 \\
10.3 \\
9.8 \\
9.6 \\
10.3 \\
10.2 \\
9.7\end{array}$ & $\begin{array}{l}4 \cdot 5 \\
4 \cdot 4 \\
3 \cdot 5 \\
5 \cdot 6 \\
5 \cdot 1 \\
3 \cdot 9 \\
3 \cdot 4 \\
4 \cdot 9 \\
4 \cdot 1 \\
4 \cdot 4 \\
4 \cdot 7 \\
4 \cdot 4\end{array}$ & $\begin{array}{r}21 \\
26 \\
9 \\
- \\
- \\
- \\
- \\
-4 \\
-\end{array}$ & $\begin{array}{l}94 \\
90 \\
80 \\
- \\
- \\
- \\
- \\
75 \\
60 \\
-\end{array}$ \\
\hline Normal range & $3 \cdot 8-32 \cdot 8$ & $90-180$ & $9 \cdot 5-11 \cdot 5$ & $3 \cdot 5-5 \cdot 5$ & $<4.5$ & \\
\hline
\end{tabular}


Despite persistent steatorrhoea and lack of supplementary vitamin $\mathrm{D}$ for considerable periods, these children have normal serum levels of 25-HCC and normal wrist $x$-rays. There is little correlation of the serum 25-HCC levels and length of ileum left, which suggests that either adequate intestinal absorption of vitamin $D$ occurs after resection of ileum or, more likely, that endogenous production in the skin can maintain adequate blood levels. It has been shown that in normal adults in this country vitamin $\mathrm{D}_{3}$ produced in the skin is the most important source of circulating $25-\mathrm{OH}$ vitamin $\mathrm{D}$ (Preece et al., 1974b).

Two patients (Cases 4 and 9) had markedly raised plasma alkaline phosphatase levels which had been constant over at least 5 years, but their plasma 25HCC levels were normal. In Case 4 the plasma alkaline phosphatase level did not change after 800 units daily oral vitamin D given for 6 months, confirming that raised plasma alkaline phosphatase concentrations were unreliable in the diagnosis of vitamin $\mathrm{D}$ deficiency in this case. This fallibility has also been shown in adolescents: 10 children with serum alkaline phosphatase levels greater than 30 King-Armstrong units had normal plasma 25HCC concentrations (Cooke et al., 1974). The normal plasma 5-nucleotidase levels in Cases 4 and 9 suggest that the liver damage associated with ileal resection in animals (Palmer, 1972) was not the cause of the raised plasma alkaline phosphatase, and the aetiology of the biochemical anomaly remains uncertain.

These studies show that despite previous recommendations supplementary vitamin $D$ is usually unnecessary for children after resection of ileum.

We thank Dr. J. L. H. O'Riordan for his encouragement and Mr. V. G. Oberholzer and the staff of the Department of Biochemistry of the Queen Elizabeth Hospital for Children for performing some of the biochemical estimations. M.A.P. is indebted to the Wellcome Foundation for financial support.

\section{REFERENCES}

Abaurre, R., Gordon, S. G., Mann, J. G., and Kern, F. (1969). Fasting bile salt pool size and composition after ileal resection. Gastroenterology, 57, 679.
Bachra, B. N., Dauer, A., and Sobel, A. E. (1958). The complexometric titration of micro and ultramicro quantities of calcium in blood serum, urine, and inorganic salt solutions. Clinical Chemistry, 4, 107.

Baker, R. D., and Searle, G. W. (1960). Bile salt absorption at various levels of rat small intestine. Proceedings of the Society for Experimental Biology and Medicine, 105, 521.

Bessey, O. A., Lowry, O. H., and Brock, M. J. (1946). A method for the rapid determination of alkaline phosphatase with 5 cubic millimeters of serum. Fournal of Biological Chemistry, $164,321$.

Booth, C. C., MacIntyre, I., and Mollin, D. L. (1964). Nutritional problems associated with extensive lesions of the distal small intestine in man. Quarterly fournal of Medicine, 33, 401.

Campbell, D. M. (1962). Determination of 5-nucleotidase in blood serum (Abst.). Biochemical fournal, 82, 34P.

Cooke, W. T., Asquith, P., Ruck, N., Melikian, V., and Swan, C. H. J. (1974). Rickets, growth and alkaline phosphatase in urban adolescents. British Medical fournal, 2, 293.

Palmer, R. H. (1972). Bile acids, liver injury, and liver disease. Archives of Internal Medicine, 130, 606.

Preece, M. A., O'Riordan, J. L. H., Lawson, D. E. M., and Kodicek, E. (1974a). A competitive protein-binding assay for 25hydroxycholecalciferol and 25-hydroxyergocalciferol in serum. Clinica Chimica Acta, 54, 235.

Preece, M. A., Tomlinson, S., Korn, H. T., Ribot, C. A., and O'Riordan, J. L. H. (1974b). Assessment of vitamin D status in man using measurement of the serum 25 hydroxycholecalciferol concentration. (Abst.) Quarterly fournal of Medicine, 43, 630.

Schachter, D., Finkelstein, J. D., and Kowarski, S. (1964). Metabolism of vitamin D. I. Preparation of radioactive vitamin D and its intestinal absorption in the rat. Fournal of Clinical Investigation, 43, 787.

Shinowara, G. Y., Jones, L. M., and Reinhart, H. L. (1942). The estimation of serum inorganic phosphate and 'acid' and 'alkaline' phosphatase activity. Fournal of Biological Chemistry, 142, 921.

Stamp, T. C. B., and Round, J. M. (1974). Seasonal changes in human plasma levels of 25 hydroxycholecalciferol. Nature (London), 247, 563.

Thompson, G. R., Lewis, B., Neale, G., and Booth, C. C. (1965). Mechanisms of vitamin $D$ deficiency in patients with lesions of the gastrointestinal tract. Quarterly fournal of Medicine, 34, 486.

Van Deest, B. W., Fordtran, J. S., Morawski, S. G., and Wilson, J. D. (1968). Bile salt and micellar fat concentration in proximal small bowel contents of ileectomy patients. Fournal of Clinical Investigation, 47, 1314.

Van de Kamer, J. H. (1958). Estimation of fatty acids in stools. Standard Methods of Clinical Chemistry, Vol. II, p. 64. Ed. by D. Seligson. Academic Press. New York.

Woodbury, J. J., Kern, F., and Palmer, M. (1970). Excretion and enterohepatic circulation of bile acids in patients with diarrhoea. (Abst.) Gastroenterology, 58, 1009.

Young, W. F., Swain, V. A. J., and Pringle, E. M. (1969). Longterm prognosis after major resection of small bowel in early infancy. Archives of Disease in Childhood, 44, 465.

Correspondence to Dr. H. B. Valman, Department of Paediatrics, Northwick Park Hospital, Watford Road, Harrow, Middlesex HA1 3UJ. 